\title{
Exploring the Relationship Between Employer Branding and Talent Management to Employee Retention: Literature Review
}

\author{
Muhamad Ekhsan', Ahmad Sudiro², Mugiono ${ }^{3}$, Ananda Sabil Hussein ${ }^{4}$ \\ \{mangunjayan@gmail.com¹, achmadsudiro@yahoo.com², mugiono@ub.ac.id ${ }^{3}$, sabil@ub.ac.id ${ }^{4}$ \} \\ Management Department, Faculty of Economics and Business, \\ Universitas Brawijaya, humas@ub.ac.id $\mathrm{d}^{1,2,3,4}$
}

\begin{abstract}
The success of a company's retention management depends on human capital management strategies implemented to ensure they retain talented employees. The challenge faced is to get employees to continue to be involved in company activities and also ensure the interest of talented employees to join the company and retention of talented employees in the company. Companies have difficulty retaining employees because they are not creative enough or their vision is not big enough. The banking industry is the most research object so research on the automotive industry especially in Indonesia is interesting because there is still little research that addresses the automotive industry. This study aims to fill the research gap. Analysis of these models will take into account the empirical literature. This review literature also makes recommendations for future research.
\end{abstract}

Keywords: Employer Branding, Talent Management, Employee Retention

\section{Introduction}

Employer branding has become a popular topic in various studies. Although this term is widely used in empirical research, there is still no universal definition [1]. For example, in market research, the attractiveness of an organization is primarily measured by brand [2]. Employer branding has been described as an organizational job designed to show current and potential employees that this is an attractive workplace [3] as it identifies the employer. Identity reflects the perceived value of the organization as an employer. The concept of employer branding is stated as the latest method that can effectively support the company's efforts to contact and retain employees. On one side, the employer strategy further enhances the company's brand image and positions the organization as a reliable and attractive organization. As previous research has shown, corporate branding is a new and exciting area with the potential to change the way companies operate. However, although this issue has attracted great interest, there are still many things that need to be clarified [4]. Many of the findings from previous studies are still inconclusive and are important predictors of the current work environment. However, personal and authoritative work practices, methods, and rules have changed, and these changes have influenced the needs and views of employees in the 21st century [5].

Today's organizations face social development challenges such as globalization, technological advances, and increasing global competition. Companies must be able to predict technological innovation and compete with other companies around the world. Apart from economic development, demographic changes also put pressure on companies. Today's society has to face the rapid aging of an active population, at the same time, fewer young people are entering the labor market, and even so-called baby boomers are gradually retiring [6]. This evolution not only led to a shortage of 
workers but also the risk of losing knowledge and experience, which companies had to face. This loss of knowledge and experience increases the importance of retaining talent, [6] explaining talent as a tool for moving the organization where it wants to be. In today's highly competitive and rapidly changing business environment, retaining and developing talent is a major concern of the organization. Labor mobility has become a common phenomenon. One reason for this is the characteristics of today's workforce, including the baby boomer generation from 1946 to 1960 , generation X from 1961 to 1980, and generation Y from 1981 to 2000. Baby boomers are nearing retirement, and generation $X$ will be retiring in a few years. . By $2030,75 \%$ of the global workforce will be Generation Y. They are the world's future workforce, and their personalities, attitudes, behaviors, and work values will be fundamentally different from those of the baby boomers and Genes [7]. Talent management is very important now. From the results of McKinsey's research this year, we can see another piece of interesting data related to talent management. which revealed some interesting things about the increasing scarcity of talent and leadership staff. Eligible employees and leaders enter the workforce to replace aging and retired leaders[8]. Besides, research results from 2012 indicated that company development was hampered by a lack of talent. In five years, an ordinary company will lose $30 \%$ of its executives. The company lacks a talented leader. When talented executives are hijacked from outside the company, the error rate is high (40-50\%). Talent management can be defined as "the development, attractiveness, engagement, retention, and placement of very high and efficient potentials to occupy key positions that have a significant impact on the organization's sustainable competitive advantage" [9]. It was originally used by McKinsey and Company in the late 1990s [10] and has been described as "the number of experiences, abilities, abilities, attitudes, and behaviors of people that can be converted into organizational performance" [11]. In the 21 st century, talent management has become one of the important challenges faced by many hotel organizations in developing countries, as demographics and relocation hurt harm human capital [12].

Within organizations, employee branding and talent management have been considered as the factors that determine employee retention rates. However, based on the theoretical research that has been carried out, there are still research gaps that can be filled. Research gaps related to the impact of employer branding on employee retention and the impact of talent management on employee retention. Based on experience, previous research has explained the significant effect of employer brands on employee retention [2], [13]-[16]. However, in the context of Egypt and Kenya, several other researchers [17], [18] did not find a significant effect on employee branding on employee retention. Just like the impact of an employer brand on employee retention, the research results also show an inconsistency in the impact of talent management on employee retention. Research conducted by [19]-[21] describes the important impact of talent management on employee retention, but some researchers such as [22] did not find the impact of talent management on employee retention in Kenya.

In recent decades, there has been increasing interest in research input, which may be because the results show that input is associated with meaningful outcomes for both the company and employees. Several quantitative studies, which show that engagement is positively correlated with job performance [23]. In recent decades, employment investment has generated more research interest, and it is still a very relevant and even a contemporary topic [24]. Work participation structure includes strength, dedication, and dedication [25]. In short, morale refers to employees who experience "high levels of energy and mental toughness at work"[25]. Service involves "a sense of meaning, passion, inspiration, pride, and challenge" in the workplace [25]. The characteristic of absorption is"

Trust is essential for a successful relationship (relationship). Trust is a multi-faceted concept (various), which captures a person's belief or belief in the integrity or reliability of other people or objects. Simply put, the concept of trust means belief. "Trust is the belief of another person or group of people, which means that you will not be risked, hurt, or hurt by them [26]." Trust is an expression of trust in another person or group of people, which means that you will not be harmed, harmed, or detained. In this study, we will discuss which indicators can be used to retain employees in the relationship between corporate branding and talent management. 


\section{Literature Review}

\subsection{Employer Branding}

Employer branding is a company effort to show current and prospective employees that their company is the ideal place to work [26]. Employer branding involves promotion both inside and outside the company, thus understanding clearly what makes a company different and what the company needs [27]. The second point of view is that employer branding is a long-term strategic goal for managing the awareness and perception of employees, prospective employees, and related stakeholders [28]. The existence of a company brand measurement angle that can be applied to employees can make it easier for each company to assess whether the company has met expectations.

The concept of employer branding is relatively new, especially in Indonesia. Therefore, few organizations are familiar with the application of the concepts developed in the United States during the last 20 years [29]. The employer brand was originally proposed by Tikson in 1996 to attract the best talent in a particular organization [30]. This concept becomes a tool for strengthening the organization's brand, making it more attractive to potential candidates, and differentiating it from other organizations.

Today, organizations are feeling competitive pressure, especially in attracting talented people to work. One way to attract talent is through corporate brand building, which emphasizes a good corporate image or reputation to attract the best talent. Companies in all sectors, including the automotive industry, face the same difficulties in finding the best talent [31]. Therefore, to maximize recruitment activities, his party seeks to attract candidates (workers) through various recruitment advertisements and use company brands. When reviewing the literature related to employer branding, it is clear that the concept involves a very clear combination or combination of marketing and human resources. According to Alnıaçık [31], marketing scholars first discussed this concept, by marketing academics and after a few years, other researchers began to have an interest in HR academics.

\subsection{Talent Management}

The term talent management was first coined by McKinsey \& Company after researching in 1997. In the second year, talent management was one of the titles of a book co-authored [32]. Talent management or talent management is a human resource management process related to these three processes. First, develop and strengthen new employees when they first enter the company (onboarding). Second, maintain and develop employees who are already in the company. Third, attracting as many employees as possible with the ability, commitment, and character to work at Simalango (2009).

Companies that consider talent management as one of their human resource management strategies do their best to link the processes of recruiting, recruiting, selecting, training, developing, nurturing, promoting, and mobilizing employees so that they are relevant to the company's core business. A strategic approach to talent management [33], [34]. Various methods of talent management, and they group four philosophies. Personnel methods, training methods, location methods, and strategy library methods [36]

\subsection{Employee Engagement}

Employee engagement as a structure consisting of cognitive, emotional, and behavioral relationships related to individual roles [35]. Employee engagement as an individual's commitment to work, satisfaction, and enthusiasm, where individuals play a role in work, stay in touch with them while performing tasks, and express themselves physically, cognitively, and emotionally [36]. Most of the references linked employee engagement to surveyors and consultants and were not academic [37]. Employee engagement construction comes from two concepts that have received academic recognition and are the subject of empirical research, namely organizational commitment and citizen 
behavior (OCB) [38]. According to Robbin's [40] definition, Employee engagement refers to the conditions for employees to be enthusiastic about their work and to build deep relationships with the organization, whereas employees without involvement or involvement devote time to work, but lack energy or energy [39]

\subsection{Organizational Trust}

Organizational trust is a global assessment of employee trust in the organization. Organizational trust is defined as the employee's belief that the organization will take actions that are beneficial or at least detrimental. Building trust is a process based on the belief that the other party will keep its promises and that the other party has good intentions about it [40]. Trust has always been one of the most important factors affecting organizational learning [41]

\section{Theoretical Framework}

\subsection{Effect of Employer Branding on Employee Retention}

Cascio [14] explained that company branding, management performance, and its relationship with employee retention have a significant effect. This finding is supported by research by Sutherland [16] that employer branding also has a direct impact on employee retention, even in Chhabra [43], employer branding is a modern corporate strategy used to reduce the cost of finding company employees.

\subsection{Effect of talent management on employee retention}

Oladapo [44] explains that talent management has a positive and significant impact on employee retention, this is supported by research conducted by Deery [45], which states that apart from research, talent management and work-life balance have a major impact on employee retention. . The survey conducted by Deery [45] was limited to companies engaged in the hotel industry, but compared to research conducted by Deery [45], many previous studies obtained similar results regarding the relationship between talent management and employee retention.

\subsection{Effect of employee engagement on employee retention}

Kennedy and Daim [47] explained that there was a significant influence between employee engagement and employee retention. In his research, employee engagement can be a major force in maintaining employee flexibility and reducing employee turnover, but his research is limited to relocated companies. In the IT industry. Previous research on job engagement found that it had a positive impact on individuals, especially leaders and organizations. Job involvement is closely related to employees' physical and mental health [48]

\subsection{Effect of organizational trust on employee retention}

Williams [49] found that organizational trust has a direct impact on employee retention. In a study using hospital nurses, researchers not only used organizational trust variables but also increased job satisfaction variables to measure their impact on employee retention. . Hussein [50] also found the same thing in his research. The existence of trust between the source and the receiver is a prerequisite for sharing knowledge between the two of them [51].

Based on previous research, some indicators can be used in the design of employer branding and talent management research. The description of each indicator can be seen in Table 1. Every important indicator needs to be understood so that the operational definition can be easier in future research. 
Table 1 Indicators on the Employer Branding, Talent Management, Employee Engagement and Organizational Trust Framework

\begin{tabular}{|c|c|c|c|}
\hline Variable & Indicator & Item & References \\
\hline \multirow{5}{*}{$\begin{array}{l}\text { Employer Branding: } \\
\text { the company's effort to } \\
\text { show current and } \\
\text { prospective employees } \\
\text { that their company is a } \\
\text { desired place to work }\end{array}$} & Application & Applied science applied by companies & \multirow[t]{5}{*}[52]{} \\
\hline & Development & Increased employee skills at work & \\
\hline & Economy & Income according to average & \\
\hline & Interest & Employee promotion & \\
\hline & Social & $\begin{array}{l}\text { Consumer satisfaction as a company } \\
\text { goal }\end{array}$ & \\
\hline \multirow{6}{*}{$\begin{array}{l}\text { Talent Management: } \\
\text { training on } \\
\text { development strategies, } \\
\text { identifying talent gaps, } \\
\text { succession planning, as } \\
\text { well as recruiting, } \\
\text { selecting, educating, } \\
\text { motivating, and } \\
\text { nurturing talented } \\
\text { employees through } \\
\text { various initiatives }\end{array}$} & $\begin{array}{l}\text { Work } \\
\text { experience }\end{array}$ & Completion of Tasks well & \multirow[t]{6}{*}[53]{} \\
\hline & Coaching & $\begin{array}{l}\text { Leadership direction in fostering } \\
\text { employees }\end{array}$ & \\
\hline & Mentoring & Leadership guidance in mentoring & \\
\hline & Training & Employee training at the company & \\
\hline & $\begin{array}{l}\text { Systematic } \\
\text { Planning }\end{array}$ & Individual job success & \\
\hline & $\begin{array}{l}\text { Career } \\
\text { development }\end{array}$ & Worker's vision for the future & \\
\hline \multirow[b]{3}{*}{$\begin{array}{l}\text { Employee Engagement: } \\
\text { involvement, } \\
\text { satisfaction, } \\
\text { enthusiasm for a person } \\
\text { to work where when } \\
\text { individuals play a role } \\
\text { in their work, bond } \\
\text { with, and express } \\
\text { themselves physically, } \\
\text { cognitively, and } \\
\text { emotionally in carrying } \\
\text { out their roles. }\end{array}$} & Intellectual & Enabling the company environment & \multirow[t]{3}{*}[54]{} \\
\hline & Social & Close co-workers & \\
\hline & Affective & The totality of individual work & \\
\hline \multirow{3}{*}{$\begin{array}{l}\text { Organizational Trust: } \\
\text { global evaluation of } \\
\text { organizational trust as } \\
\text { perceived by employees }\end{array}$} & Virtue & Work management that goes well & \multirow[t]{3}{*}{ [42] } \\
\hline & Integrity & The ability of workers in their fields & \\
\hline & Ability & The company's ability in its field & \\
\hline
\end{tabular}

\section{Conclusions}

In the last few decades, employee retention has become popular research, because there are many opportunities and business developments that continue to develop, so that employee retention is very important in the company. It can be seen from the previous research literature that employer brand variables can be measured using application, development, economic, interest, and social indicators. Talent management variables can be measured by indicators of work experience, coaching, mentoring, training, systematic planning, and career development. Based on experience, previous studies have explained the significant impact of corporate branding on employee retention [56, 14, 16]. However, in the Egyptian and Kenyan context, several other researchers [18] did not find a 
significant impact of employee branding on employee retention. Just like the impact of an employer brand on employee retention, the research results also show an inconsistency in the impact of talent management on employee retention. Research [19] described the important impact of talent management on employee retention, but several other researchers [22] did not find the impact of talent management on employee retention in Kenya. Judging from the results of previous studies, the findings between one researcher and another are inconsistent. It is hoped that further research can be carried out from these findings to determine the factors that influence the variable employer brand and employee talent management retention.

\section{References}

[1] T. V. Bondarouk and H. J. M. Ruël, "Electronic human resource management: Challenges in the digital era," International Journal of Human Resource Management. 2009, doi: 10.1080/09585190802707235.

[2] K. Backhaus and S. Tikoo, "Conceptualizing and researching employer branding," Career Dev. Int., vol. 9, no. 5, pp. 501-517, 2004, doi: 10.1108/13620430410550754.

[3] S. Lloyd, "Branding from the inside out," Bus. Rev. Wkly. - BRW, 2002.

[4] A. Näppä, "Creating a Strong Service Brand Through Talent: The Relationship Between Corporate, Internal and Employer Branding," Luleå University of Technology, 2013.

[5] F. Lievens, "Employer branding in the Belgian Army: The importance of instrumental and symbolic beliefs for potential applicants, actual applicants, and military employees," Hum. Resour. Manage., vol. 46, no. 1, pp. 51-69, 2007.

[6] N. Govaerts, E. Kyndt, F. Dochy, and H. Baert, "Influence of learning and working climate on the retention of talented employees," J. Work. Learn., 2011, doi: $10.1108 / 13665621111097245$.

[7] M. F. Naim and U. Lenkla, "Knowledge sharing as an intervention for Gen Y employees' intention to stay," Ind. Commer. Train., 2016, doi: 10.1108/ICT-01-2015-0011.

[8] M. Guthridge, A. B. Komm, and E. Lawson, "Making talent a strategic priority," McKinsey Q., 2008.

[9] E. Gallardo-Gallardo and M. Thunnissen, "Standing on the shoulders of giants? A critical review of empirical talent management research," Employee Relations. 2016, doi: 10.1108/ER-10-2015-0194.

[10] E. L. Axelrod, H. Handfield-Jones, and T. a. Welsh, "War for talent , part two," McKinsey Q., 2001, doi: 10.1080/03071840308446873.

[11] P. R. Pillai, "Influence Of HRD Climate On The Learning Orientation Of Bank Employees," Indian J. Ind. Relat., 2008.

[12] J. Svejnar, "Transition Economies: Performance and Challenges," J. Econ. Perspect., vol. 16, no. 1, pp. 3-28, 2002, doi: 10.1257/0895330027058.

[13] M. Asuman, K. Francis, and M. Sam, "Employer branding and talent retention: perceptions of employees in higher education institutions in Uganda," Ind. Commer. Train., vol. 50, no. 5, pp. 217-233, Jan. 2018, doi: 10.1108/ICT-03-2018-0031.

[14] W. F. Cascio, "Leveraging employer branding, performance management and human resource development to enhance employee retention," Hum. Resour. Dev. Int., 2014, doi: 10.1080/13678868.2014.886443.

[15] M. R. Edwards, "An integrative review of employer branding and OB theory," Personnel Review. 2009, doi: 10.1108/00483481011012809.

[16] M. M. Sutherland, D. G. Torricelli, and R. F. Karg, "Employer-of-choice branding for knowledge workers," South African J. Bus. Manag., 2002, doi: 10.4102/sajbm.v33i4.707.

[17] T. A. Al Badawy, V. M. Fahmy, and M. M. Magdy, "Can Employer Branding Surge the Retention and Motivation of Egyptian Employees?," in Competition Forum, 2015, vol. 13, no. 2, p. 253.

[18] S. O. OOKO and J. Nzulwa, "Influence of Employer Branding on Retention of Staff in Broadcasting Media Firms in Kenya," Strateg. J. Bus. Chang. Manag., vol. 4, no. 1, pp. 201-215, 2017.

[19] J. C. Hughes and E. Rog, "Talent management: A strategy for improving employee 
recruitment, retention and engagement within hospitality organizations," Int. J. Contemp. Hosp. Manag., vol. 20, no. 7, pp. 743-757, 2008.

[20] V. Oladapo, "The impact of talent management on retention," J. Bus. Stud. Q., vol. 5, no. 3, p. 19,2014

[21] P. Vaijayanthi, K. A. Shreenivasan, and S. Prabhakaran, "Employee Engagement predictors: A study at GE Power \& Water.," Int. J. Glob. Bus., 2011.

[22] A. W. Kibui, H. Gachunga, and G. S. Namusonge, "Role of talent management on employees retention in Kenya: A survey of state corporations in Kenya: Empirical review," Int. J. Sci. Res., vol. 3, no. 2, pp. 414-424, 2014.

[23] A. B. Bakker and E. Demerouti, "Towards a model of work engagement," Career Dev. Int., 2008.

[24] O. M. Karatepe and G. Karadas, "Do psychological capital and work engagement foster frontline employees' satisfaction?," Int. J. Contemp. Hosp. Manag., 2015.

[25] W. B. Schaufeli, M. Salanova, V. González-Romá, and A. B. Bakker, "The measurement of engagement and burnout: A two sample confirmatory factor analytic approach," $J$. Happiness Stud., vol. 3, no. 1, pp. 71-92, 2002.

[26] G. George, A. M. McGahan, and J. Prabhu, "Innovation for inclusive growth: Towards a theoretical framework and a research agenda," J. Manag. Stud., vol. 49, no. 4, pp. 661-683, 2012.

[27] E. Sokro, "Impact of employer branding on employee attraction and retention," Eur. J. Bus. Manag., vol. 4, no. 18, pp. 164-173, 2012.

[28] M. Suby, "The 2013 (ISC) 2 Global Information Security Workforce Study," Iamcybersafe.Org, 2013.

[29] S. D. S. Tikson, N. Hamid, and R. Mardiana, "Employer Branding as a Strategy to Attract Potential Workforce," Bisnis Birokrasi J., vol. 25, no. 3, 2018.

[30] V. Franca and M. Pahor, "The strength of the employer brand: Influences and implications for recruiting.," J. Mark. Manag., vol. 3, no. 1, 2012.

[31] E. Alnıaçık, Ü. Alnıaçık, S. Erat, and K. Akçin, "Attracting talented employees to the company: Do we need different employer branding strategies in different cultures?," Procedia-Social Behav. Sci., vol. 150, pp. 336-344, 2014.

[32] E. Michaels, H. Handfield-Jones, and B. Axelrod, The war for talent. Harvard Business Press, 2001.

[33] J. W. Boudreau and P. M. Ramstad, “Talentship, talent segmentation, and sustainability: A new HR decision science paradigm for a new strategy definition," Hum. Resour. Manag. Publ. Coop. with Sch. Bus. Adm. Univ. Michigan alliance with Soc. Hum. Resour. Manag., vol. 44, no. 2, pp. 129-136, 2005.

[34] D. G. Collings and K. Mellahi, "Strategic talent management: A review and research agenda," Hum. Resour. Manag. Rev., vol. 19, no. 4, pp. 304-313, 2009.

[35] P. R. Sparrow and H. Makram, "What is the value of talent management? Building valuedriven processes within a talent management architecture," Hum. Resour. Manag. Rev., vol. 25, no. 3, pp. 249-263, 2015.

[36] W. B. Schaufeli, "What is engagement," Empl. Engagem. theory Pract., vol. 15, p. 321, 2013.

[37] S. L. Albrecht, "Employee engagement: 10 key questions for research and practice.," 2010.

[38] D. Robinson, S. Perryman, and S. Hayday, "The drivers of employee engagement," ReportInstitute Employ. Stud., 2004.

[39] S. P. Robbins, T. Judge, and N. Langton, Fundamentals of organizational behaviour. W. Ross MacDonald School Resource Services Library, 2013.

[40] P. Paillé, L. Bourdeau, and I. Galois, "Support, trust, satisfaction, intent to leave and citizenship at organizational level," Int. J. Organ. Anal., 2010.

[41] T. H. Davenport and L. Prusak, Working knowledge: How organizations manage what they know. Harvard Business Press, 1998.

[42] Y. Cui and H. Jiao, "Organizational justice and management trustworthiness during organizational Change: Interactions of Benevolence, Integrity, and managerial approaches," Inf. Process. Manag., vol. 56, no. 4, pp. 1526-1542, 2019. 
